\title{
Effect of $W$ on the Impact-Induced Energy Release Behavior of Al-Ni Energetic Structural Materials
}

\author{
Shun $\mathrm{Li}^{1}$, Caimin Huang ${ }^{1,2, *}$, Jin Chen ${ }^{3}$, Yu Tang ${ }^{1, *}$ and Shuxin Bai ${ }^{1}$ \\ 1 Department of Materials Science and Engineering, College of Aerospace Science and Engineering, \\ National University of Defense Technology, Changsha 410073, China; linudt@163.com (S.L.); \\ nudt_rms_501@163.com (S.B.) \\ 2 School of Mechanical and Electrical Engineering, Guilin University of Electronic Technology, \\ Guilin 541004, China \\ 3 Xi'an Modern Chemistry Research Institute, Xi'an 710065, China; chenjin204s@163.com \\ * Correspondence: huangcaimin123@163.com (C.H.); tangyu15@zju.edu.cn (Y.T.); Tel.: +86-731-84576147 (Y.T.)
}

check for updates

Citation: Li, S.; Huang, C.; Chen, J.; Tang, Y.; Bai, S. Effect of W on the Impact-Induced Energy Release Behavior of Al-Ni Energetic Structural Materials. Metals 2021, 11, 1217. https://doi.org/10.3390/ met11081217

Academic Editor: Tilmann Beck

Received: 24 June 2021

Accepted: 26 July 2021

Published: 30 July 2021

Publisher's Note: MDPI stays neutral with regard to jurisdictional claims in published maps and institutional affiliations.

Copyright: (c) 2021 by the authors. Licensee MDPI, Basel, Switzerland. This article is an open access article distributed under the terms and conditions of the Creative Commons Attribution (CC BY) license (https:// creativecommons.org/licenses/by/ $4.0 /)$.

\begin{abstract}
Energetic structural materials (ESMs) are an important class of military materials due to their good structural and energy-releasing characteristics. To improve the damage effect of metalmetal ESMs with good mechanical properties, $\mathrm{W}$ was added to the $48 \mathrm{Al}-52 \mathrm{Ni}$ composites, and the effect of $\mathrm{W}$ on the impact-induced energy release behaviors was investigated. The results showed that the hot-press process and the addition of $\mathrm{W}$ did not change the microstructure and surface state of the constituent particles, leading to a stable onset temperature of the $\mathrm{Al}-\mathrm{Ni}$ intermetallic reaction in (48Al-52Ni) ${ }_{100-x} \mathrm{~W}_{x}$ composites. Meanwhile, the decrease in the contact area between $\mathrm{Al}$ and $\mathrm{Ni}$ in the composites with increased $\mathrm{W}$ content resulted in the decrease in reaction heat. During the impact process, the intermetallic reaction of $\mathrm{W}$ caused by the Al-Ni intermetallic reaction, as well as the oxidation reaction of $\mathrm{Al}$ and $\mathrm{Ni}$ caused by the brittle fracture along the weak interface, caused the released energy of $(48 \mathrm{Al}-52 \mathrm{Ni})_{40} \mathrm{~W}_{60}$ to reach $2.04 \mathrm{~kJ} / \mathrm{g}$.
\end{abstract}

Keywords: energetic structural materials; Al-Ni composite; W; impact-induced reaction; energy release characteristic

\section{Introduction}

Energetic structural materials (ESMs), also called reactive materials or multi-functional structural energetic materials (MSEM), are a class of novel structural materials [1]. ESMs are inert under ambient conditions, but reactions between components or with the atmosphere during application cause them to release amounts of chemical energy [2-4], leading to additional collateral damage [5]. ESMs with high density, excellent mechanical properties, and energy release characteristics seem to be the best materials for reactive fragments, shaped charges, and reactive bullets $[4,6]$.

According to the component, ESMs are distinguished as three types: metal-fluoropolymer (such as Al-PTFE, etc.), metal-oxide (such as $\mathrm{Al}-\mathrm{Fe}_{2} \mathrm{O}_{3}, \mathrm{Al}-\mathrm{CuO}, \mathrm{Al}-\mathrm{MnO}_{2}, \mathrm{Al}-\mathrm{MoO}_{3}$, etc.), and metal-metal (such as $\mathrm{Al}-\mathrm{Ni}, \mathrm{Al}-\mathrm{Hf}, \mathrm{Al}-\mathrm{Nb}, \mathrm{Al}-\mathrm{Ta}, \mathrm{W}-\mathrm{Zr}$, etc.) [7-10]. Among them, metal-metal ESMs have the best mechanical properties and can satisfy the needs of load-carrying structures. The damage effects of metal-metal ESMs became the key for application and were extensively investigated.

The damage effects of ESMs are dependent on kinetic energy and additional chemical energy released from impact-induced reactions. The improvement of damage effects has two components. The first one is composition optimization. For example, PTFE may be introduced in $\mathrm{Al}-\mathrm{Ni}$ composites to promote an Al-PTFE reaction with a high heat reaction $\left(55.67 \mathrm{~kJ} / \mathrm{g}\right.$ [11]) during impact loading [12]. Other oxides, e.g., $\mathrm{CuO}$ or $\mathrm{MoO}_{3}$, which can react with $\mathrm{Al}$ and release a large amount of energy, were also added into the $\mathrm{Al}-\mathrm{Ni}$ composites [13]. The addition of a non-metal improves the energy release performance of metal-metal ESMs, but it also leads to the collapse of mechanical properties. 
The second way to improve the damage effects of metal-metal ESMs is the addition of a high-density component, which can greatly improve the kinetic energy of ESMs. For example, introducing $\mathrm{W}$, whose density is $19.35 \mathrm{~g} / \mathrm{cm}^{3}$, causes the combustion heat per unit volume to reach $21,150 \mathrm{cal} / \mathrm{cm}^{3}$ [14] in Al-Ni composites [15]. The released energy per unit mass of $\mathrm{Al}-\mathrm{Ni}$ composites with $\mathrm{W}$ can reach from $0.93 \mathrm{~kJ} / \mathrm{g}$ to $2.23 \mathrm{~kJ} / \mathrm{g}$ at an impact velocity of $1176 \mathrm{~m} / \mathrm{s}$ [15]. The reaction mechanism of Al-Ni composites induced by heating has been widely investigated in previous work. Rogachev et al. presented that solid $\mathrm{Ni}$ was dissolved in $\mathrm{Al}$ and subsequently generated $\mathrm{Ni}-\mathrm{Al}$ intermetallics, accompanied by the formation of a large amount of melt [16]. The combustion temperature of Al-Ni composites reached $1638^{\circ} \mathrm{C}$ during the formation of intermetallics [17]. The presence of high temperatures and a liquid phase is conducive to the dissolving of $\mathrm{W}$ in $\mathrm{Al}$ and $\mathrm{Ni}$. Shchukin et al. reported that when $\mathrm{W}$ was partially dissolved in Al-Ni-W composites, the shape of the $\mathrm{W}$ particles was changed during the formation of $\mathrm{Ni}-\mathrm{Al}$ intermetallic and finally obtained the pseudobinary eutectic $\mathrm{Ni}-\mathrm{Al}-\mathrm{W}$ system [17]. W remained a pure metal after the Al-Ni intermetallic reaction, indicating that $\mathrm{W}$ cannot take part in an intermetallic reaction. Although the positive effect of $W$ on metal-metal ESMs, especially Al-Ni composites, has been demonstrated, the impact-induced reaction mechanism is not clear due to the difficulty in the analysis of the reaction process.

In this work, a classic metal-metal ESMs 48Al-52Ni (wt.\%) composite is proposed. The effect of $\mathrm{W}$ on the impact-induced energy release behavior of Al-Ni ESMs is revealed from the microstructure, thermal reaction behavior, mechanical properties, and reaction product.

\section{Materials and Methods}

Al (spherical, $5 \mu \mathrm{m}$, purity: 99.9\%), carbonyl Ni (spherical, $5 \mu \mathrm{m}$, purity: 99.8\%), and $\mathrm{W}$ (spherical, $3 \mu \mathrm{m}$, purity: 99.5\%) raw powders were mixed by ball milling. These raw powders were purchased from Changsha Tianjiu Metal Material Co. Ltd. The ballto-powder mass ratio, rotate speed, and milling time was 10:1, $250 \mathrm{r} / \mathrm{min}$, and $20 \mathrm{~min}$, respectively. The mixtures were pressed in an argon atmosphere under a pressure of $600 \mathrm{MPa}$ at $673 \mathrm{~K}$ for $2 \mathrm{~h}$ to plates with a size of $50 \mathrm{~mm} \times 30 \mathrm{~mm} \times 13 \mathrm{~mm}$. Some cylindrical samples $(\Phi 10 \mathrm{~mm} \times 10 \mathrm{~mm})$ and dish-like samples with a thickness of $0.3 \mathrm{~mm}$ were machined for subsequent experiments.

X-ray diffraction (XRD, Smartlab 9KW) with $\mathrm{Cu} \mathrm{K} \alpha$ radiation $(\lambda=1.5406 \AA)$ and scanning electron microscopy (SEM, JSM-6490LV) equipped with energy-disperse spectroscopy (EDS) were used to investigate the microstructure of composites. The valence state of the components was determined by X-ray photoelectron spectroscopy (XPS, EscaLab Xi+) with $\mathrm{Al} \mathrm{K} \alpha$ rays (1486.6 eV). To calibrate the spectrum, a binding energy of $284.8 \mathrm{eV}$ for the $\mathrm{C} 1 \mathrm{~s}$ peak was selected. Thermal reaction behaviors were conducted by thermogravimetric and differential scanning calorimetry (TG-DSC) (STA449F3, Jupiter, NETZSCH). The samples (about 6-10 mg) were heated to $1273 \mathrm{~K}$ at a heating rate of $10 \mathrm{~K} / \mathrm{min}$ in a high-purity argon atmosphere $(40 \mathrm{~mL} / \mathrm{min})$. Quasi-static compressive tests were carried out using an Instron 3369 testing system at a strain rate of $10^{-3} \mathrm{~s}^{-1}$.

Impact-induced reaction behaviors were measured by ballistic tests, which were shown in our previous work [18]. The released energy caused by the impact of (48Al$52 \mathrm{Ni})_{100-x} \mathrm{~W}_{x}$ (wt.\%, $x=0,25,40,50$, and 60) composites were calculated by the classic empirical equation [19].

$$
\Delta E=\frac{\Delta P V}{\gamma-1}
$$

where $\Delta E$ is released energy, $\Delta P$ is the maximum value of overpressure (the tested pressure minus the atmospheric pressure) in the test container, $V$ is the volume of the test container, $\gamma$ is the ratio of $C_{\mathrm{p}}$ to $C_{V}$. In the present work, $V$ is $27 \mathrm{~L}$, and $\gamma$ is 1.4 . 


\section{Results and Discussion}

\subsection{Microstructure of $(48 \mathrm{Al}-52 \mathrm{Ni})_{100-x} \mathrm{~W}_{x}$ Composites}

Figures 1 and 2 present the backscattered electron (BSE) images and XRD patterns of hot-pressed (48Al-52Ni) $)_{100-x} \mathrm{~W}_{x}(x=25,40,50$, and 60) composites. As shown in Figure 1 , all these samples are composed of a black matrix phase and gray and white dispersed phases, although the volume fraction of black matrix decreases as the content of $W$ in the composites increases from $25 \mathrm{wt} \%$ to $60 \mathrm{wt} . \%$. According to EDS results, the black, gray, and white regions are the pure metals $\mathrm{Al}, \mathrm{Ni}$, and $\mathrm{W}$, respectively. They agree with the results shown in Figure 2, where only the diffraction peaks corresponding to $\mathrm{Al}, \mathrm{Ni}$, and $\mathrm{W}$ can be observed.
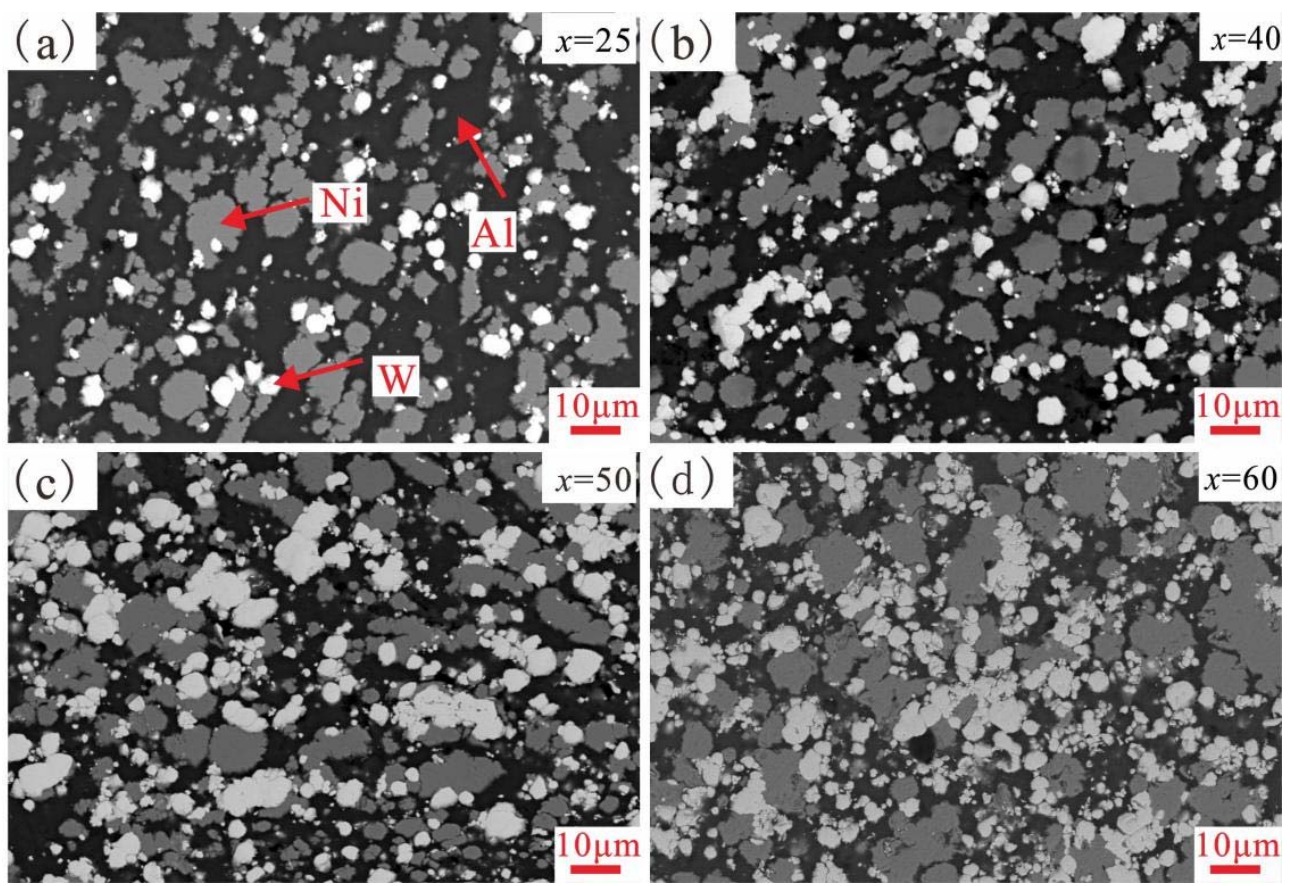

Figure 1. BSE images of the hot-pressed (48Al-52Ni) ${ }_{100-x} \mathrm{~W}_{x}$ composites. (a) $x=25$; (b) $x=40$; (c) $x=50 ;$ (d) $x=60$.

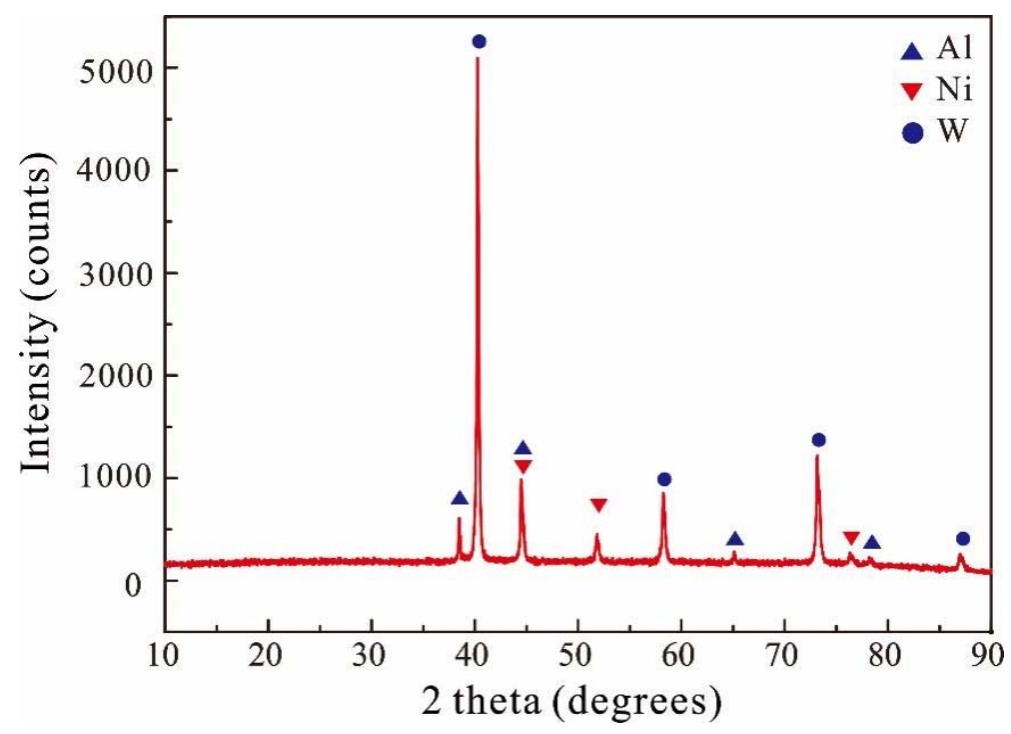

Figure 2. XRD patterns of the hot-pressed $(48 \mathrm{Al}-52 \mathrm{Ni})_{40} \mathrm{~W}_{60}$ composites.

The presence of $\mathrm{Al}, \mathrm{Ni}$, and $\mathrm{W}$ in hot-pressed (48Al-52Ni) ${ }_{100-x} \mathrm{~W}_{x}$ composites indicates that the intermetallic-forming reaction between constituent elements did not occur because 
the hot-pressed temperature of this work was $673 \mathrm{~K}$, which is much lower than the reaction onset temperature for micro-sized $\mathrm{Al}-\mathrm{Ni}, \mathrm{Al}-\mathrm{W}$, and $\mathrm{Ni}-\mathrm{W}$ composites [20-22].

Previous works have revealed that the formation of Al-Ni intermetallic is a diffusioncontrolled solid reaction and is mainly decided by the interface between $\mathrm{Al}$ and $\mathrm{Ni}$ [18] The effect of $\mathrm{W}$ on the $\mathrm{Al} / \mathrm{Ni}$ interface is investigated by the XPS spectrum of $\mathrm{Al}$ and $\mathrm{Ni}$. As shown in Figure 3, the binding energy of $\mathrm{Al}$ and $\mathrm{Ni}$ on the surface state, including ionic and atomic states, are independent of the presence of $\mathrm{W}$. This suggests that $\mathrm{W}$ has a slight effect on the surface states of $\mathrm{Al}$ and $\mathrm{Ni}$.
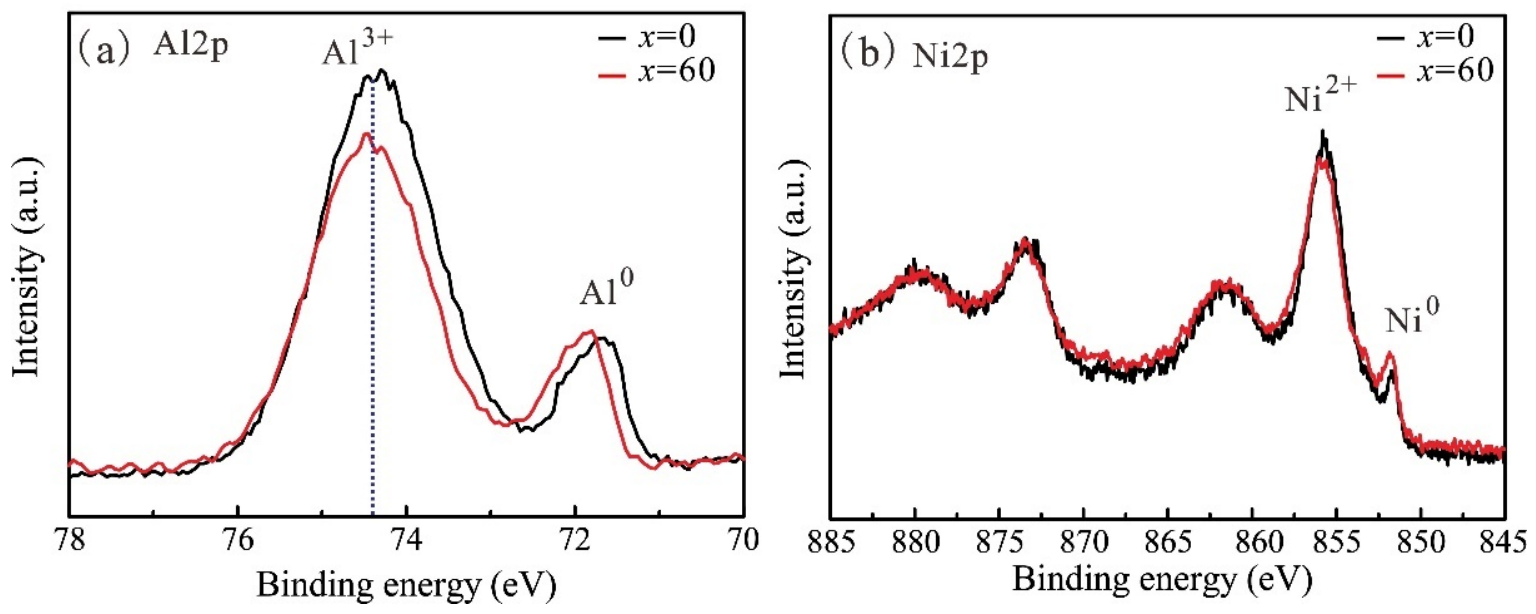

Figure 3. XPS patterns of $\mathrm{Al} 2 \mathrm{p}_{3 / 2}$ and $\mathrm{Ni} 2 \mathrm{p}_{3 / 2}$ spectra of $(48 \mathrm{Al}-52 \mathrm{Ni})_{40} \mathrm{~W}_{60}$ composites at room temperature. (a) $\mathrm{Al} 2 \mathrm{p}_{3 / 2}$; (b) $\mathrm{Ni} 2 \mathrm{p}_{3 / 2}$.

\subsection{Thermal Reaction Behavior of $(48 \mathrm{Al}-52 \mathrm{Ni})_{100-x} \mathrm{~W}_{x}$ Composites}

Figure 4 presents the DSC curves of $(48 \mathrm{Al}-52 \mathrm{Ni})_{100-x} \mathrm{~W}_{x}$ composites protected with Ar gas. As can be seen, while the reaction onset temperature is stable in the region of $760-790 \mathrm{~K}$, the total heat of reaction sharply reduces from $\sim 1300 \mathrm{~J} / \mathrm{g}$ to $\sim 600 \mathrm{~J} / \mathrm{g}$ as $x$ increases from 0 to 60 . Notably, an endothermic reaction peak at approximately $1140 \mathrm{~K}$ disappears when $\mathrm{W}$ is added.

Figure 5 shows the microstructure of $(48 \mathrm{Al}-52 \mathrm{Ni})_{100-x} \mathrm{~W}_{x}$ composites annealed at $790 \mathrm{~K}$ for 20 min. Aided by the results of EDS, the $\mathrm{Al}_{3} \mathrm{Ni}$ and $\mathrm{Al}_{3} \mathrm{Ni}_{2}$ phase can be found in the annealed 48Al-52Ni composites (Figure 5a), while the $\mathrm{Al}$ and Ni particles disappear. By contrast, the $\mathrm{Al}_{3} \mathrm{Ni}$ phase is absent in the annealed composites with $\mathrm{W}$, where many $\mathrm{W}$ particles and $\mathrm{Al}_{4} \mathrm{~W}$ compounds are detected.

On the one hand, the onset temperature of exothermic reaction is dependent on the reaction type and the surface state of the reactants. According to the previous work, the exothermic reaction that starts at $760-790 \mathrm{~K}$ in $(48 \mathrm{Al}-52 \mathrm{Ni})_{100-x} \mathrm{~W}_{x}$ composites is the intermetallic reaction between $\mathrm{Al}$ and $\mathrm{Ni}$. Meanwhile, the surface state of $\mathrm{Al}$ and $\mathrm{Ni}$ particles is rarely dependent on the content of $\mathrm{W}$ in the (48Al-52Ni) ${ }_{100-x} \mathrm{~W}_{x}$ composites, as shown in Figure 3. Thus, the onset temperature of (48Al-52Ni) ${ }_{100-x} \mathrm{~W}_{x}$ composites is relatively stable, as shown in Figure 4.

On the other hand, the heat released from the exothermic reaction is dependent on the contact area between reactants. As shown in Figure 1, the contact area between $\mathrm{Al}$ and $\mathrm{Ni}$ particles in the composites decreases as $\mathrm{W}$ content increases. Thus, the heat released in (48Al-52Ni) ${ }_{100-x} \mathrm{~W}_{x}$ composites is clearly reduced in the composites with a higher $\mathrm{W}$ content, as shown in Figure 4.

Moreover, according to the previous work [18], the endothermic reaction at approximately $1140 \mathrm{~K}$ in the $\mathrm{Al}-\mathrm{Ni}$ composite is regarded as the melting of $\mathrm{Al}_{3} \mathrm{Ni}$. The absence of the melting of $\mathrm{Al}_{3} \mathrm{Ni}$ indicates the absence of the $\mathrm{Al}_{3} \mathrm{Ni}$ phase and the change of Al-Ni reaction in the composites with $\mathrm{W}$. The analysis for the reaction product of $(48 \mathrm{Al}-52 \mathrm{Ni})_{100-x} \mathrm{~W}_{x}$ composites (Figure 5) agrees with this phenomenon. 

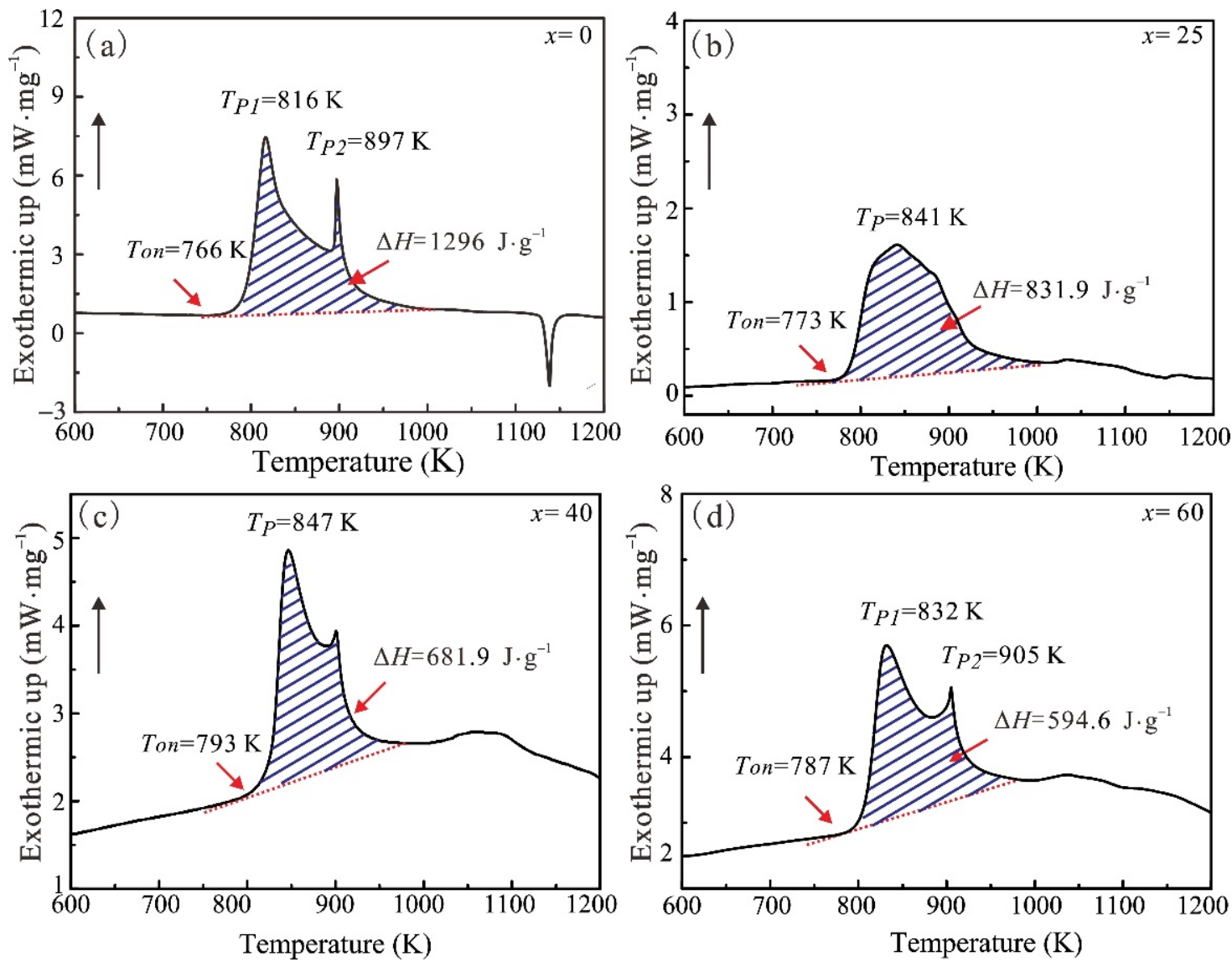

Figure 4. DSC curves of (48Al-52Ni) ${ }_{100-x} \mathrm{~W}_{x}$ composites (a) $x=0 ;$ (b) $x=25 ;$ (c) $x=40 ;$ (d) $x=60$.
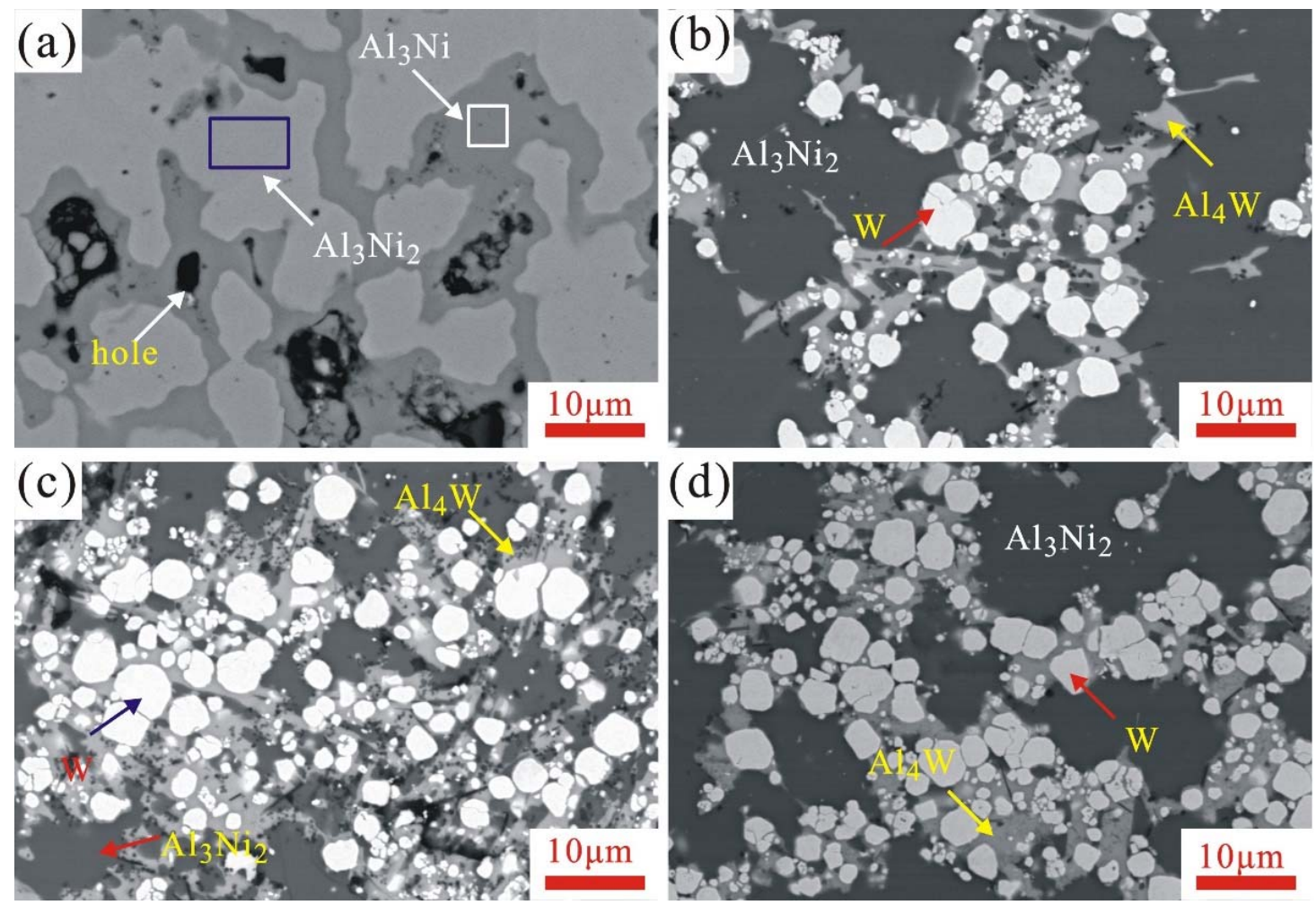

Figure 5. Microstructures of annealed (48Al-52Ni) ${ }_{100-x} \mathrm{~W}_{x}$ composites. (a) $x=0$; (b) $x=25$; (c) $x=40$; (d) $x=60$. 
According to the report of the reaction mechanism for Al-Ni composites [23], the $\mathrm{Al}_{3} \mathrm{Ni}$ phase first formed at the $\mathrm{Al} / \mathrm{Ni}$ interface, and then the $\mathrm{Al}_{3} \mathrm{Ni}_{2}$ phase was generated through the diffusion of $\mathrm{Ni}$. Two exothermic peaks for all (48Al-52Ni) ${ }_{100-x} \mathrm{~W}_{x}$ composites at 700-1000 K (Figure 4) and the presence of $\mathrm{Al}_{3} \mathrm{Ni}_{2}$ in all annealed composites jointly demonstrates the same $\mathrm{Al}-\mathrm{Ni}$ intermetallic-forming reaction process in the composites with W.

$\mathrm{Al}$ reacts with $\mathrm{Ni}$ accompanied by distinct self-heating in an equiatomic mixture of $\mathrm{Ni}-\mathrm{Al}$ powders, producing a large amount of liquid phase in the form of Ni-Al melt [21]. This self-heating phenomenon causes the temperature to reach 1550 reported in [17]. The temperature is high enough to dissolve $\mathrm{W}$ in $\mathrm{Al}$ and Ni phases, and the solubility of $\mathrm{W}$ is dependent on the diffusion of metals at $\mathrm{W} / \mathrm{Al}$ and $\mathrm{W} / \mathrm{Ni}$ solid-liquid interface. When the temperature is above $1300{ }^{\circ} \mathrm{C}$, the solubility of $\mathrm{W}$ in the $\mathrm{Al}$ phase increases to $15 \mathrm{At} . \%[24,25]$, while when the temperature rises to $1510^{\circ} \mathrm{C}$, the solubility of $\mathrm{W}$ in the Ni phase increases to 17.5 at.\% [24,25]. In other words, as long as the chemical reaction between $\mathrm{Al}$ and $\mathrm{Ni}$ initiates, the $\mathrm{Al}$ and Ni phases can dissolve W. Some $\mathrm{Al}-\mathrm{W}$ and Ni-W compounds generate with sufficient diffusion time [26]. Thus, the presence of Al4W and Ni4W, as shown in Figure 5, is the result of diffusion and reaction for Al-W and Ni-W systems. The reaction of $\mathrm{Al}-\mathrm{W}$ would consume a certain amount of $\mathrm{Al}$, which changes the ratio between $\mathrm{Al}$ and $\mathrm{Ni}$, resulting in the absence of $\mathrm{Al}_{3} \mathrm{Ni}$, as shown in Figures 4 and 5.

\subsection{Impact-Induced Energy Release Behaviors of $(48 \mathrm{Al}-52 \mathrm{Ni})_{100-x} W_{x}$ Composites}

Figure 6 shows the quasi-static overpressure (the tested pressure minus the atmospheric pressure) in the test chamber caused by the impact of $(48 \mathrm{Al}-52 \mathrm{Ni})_{100-x} \mathrm{~W}_{x}(x=0,25$, 40,50 , and 60) composites with a velocity of $1200 \mathrm{~m} / \mathrm{s}$. As can be seen from Figure 6a,c, the penetration of the (48Al-52Ni) ${ }_{100-x} \mathrm{~W}_{x}$ composites causes an obvious flame and a sharp increase in gas pressure in the test chamber within $10 \mathrm{~ms}$. Subsequently, the gas pressure in the test chamber gradually reduces to atmospheric pressure due to the presence of the bullet hole connecting with the environment (Figure $6 \mathrm{~b}$ ) and the temperature rise caused by the reaction of the (48Al-52Ni $)_{100-x} \mathrm{~W}_{x}$ composites vanishes. The dependence of released energy calculated by Equation (1) on the $\mathrm{W}$ content in (48Al-52Ni) ${ }_{100-x} \mathrm{~W}_{x}$ composites are shown in Figure $6 \mathrm{~d}$. The released energy caused by the penetration of $(48 \mathrm{Al}-52 \mathrm{Ni})_{100-x} \mathrm{~W}_{x}$ composites increases from $0.83 \mathrm{~kJ} / \mathrm{g}$ to $2.04 \mathrm{~kJ} / \mathrm{g}$ as $x$ increases from 0 to 60 .

Figure 7 presents the XRD pattern and SEM images of the collected fragments of the (48Al-52Ni) ${ }_{40} \mathrm{~W}_{60}$ composites. In the first XRD pattern (Figure 7a), a set of strong diffraction peaks are identified as $\mathrm{W}$, while other weak diffraction peaks can be attributed to $\mathrm{Al}_{3} \mathrm{Ni}_{2}, \mathrm{Ni}_{4} \mathrm{~W}, \mathrm{Al}_{2} \mathrm{O}_{3}, \mathrm{NiWO}_{4}$, and oxide-scale of $\mathrm{W}$, respectively, but not $\mathrm{Al}$ and $\mathrm{Ni}$. The collected fragments are divided into two types: irregular and spherical fragments. According to EDS results shown in Table 1 and Figure 8, it can be known that the irregular fragments are composites of $\mathrm{Al}_{3} \mathrm{Ni}_{2}$ (dark gray region), $\mathrm{W}$ (white spherical region), and $\mathrm{Al}_{4} \mathrm{~W}$ (gray region), and the spherical fragments are composites of $\mathrm{W}$ (white spherical region), $\mathrm{Ni}_{4} \mathrm{~W}$ (gray region), and $\mathrm{Al}_{2} \mathrm{O}_{3}$ (black spherical region).

Table 1. EDS results of Figure 7 (at.\%).

\begin{tabular}{cccccc}
\hline & Al & Ni & W & O & Phase \\
\hline A & - & 6.0 & 94.0 & - & $\mathrm{W}$ \\
B & 64.7 & 35.3 & - & - & $\mathrm{Al}_{3} \mathrm{Ni}_{2}$ \\
C & 78.9 & - & 21.1 & - & $\mathrm{Al}_{4} \mathrm{~W}$ \\
D & 57.0 & 79.3 & 20.7 & 43.0 & $\mathrm{Al}_{2} \mathrm{O}_{3}$ \\
E & - & - & - & $\mathrm{Ni}_{4} \mathrm{~W}$ \\
\hline
\end{tabular}



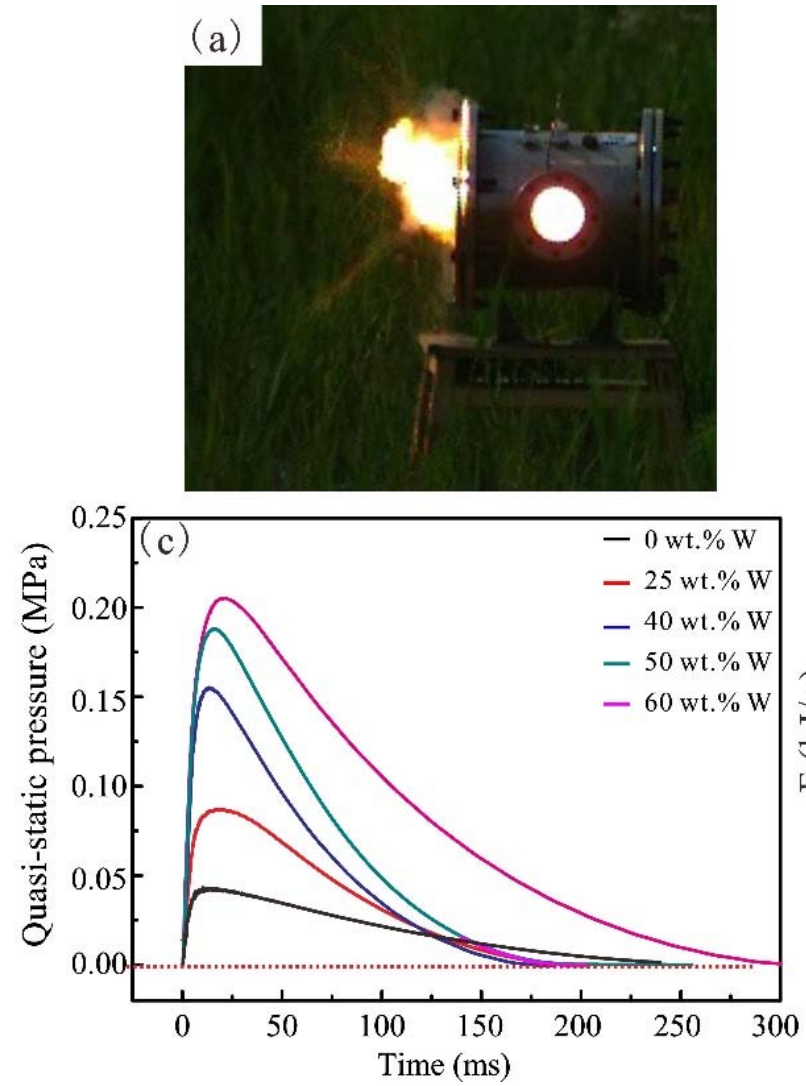

(b)
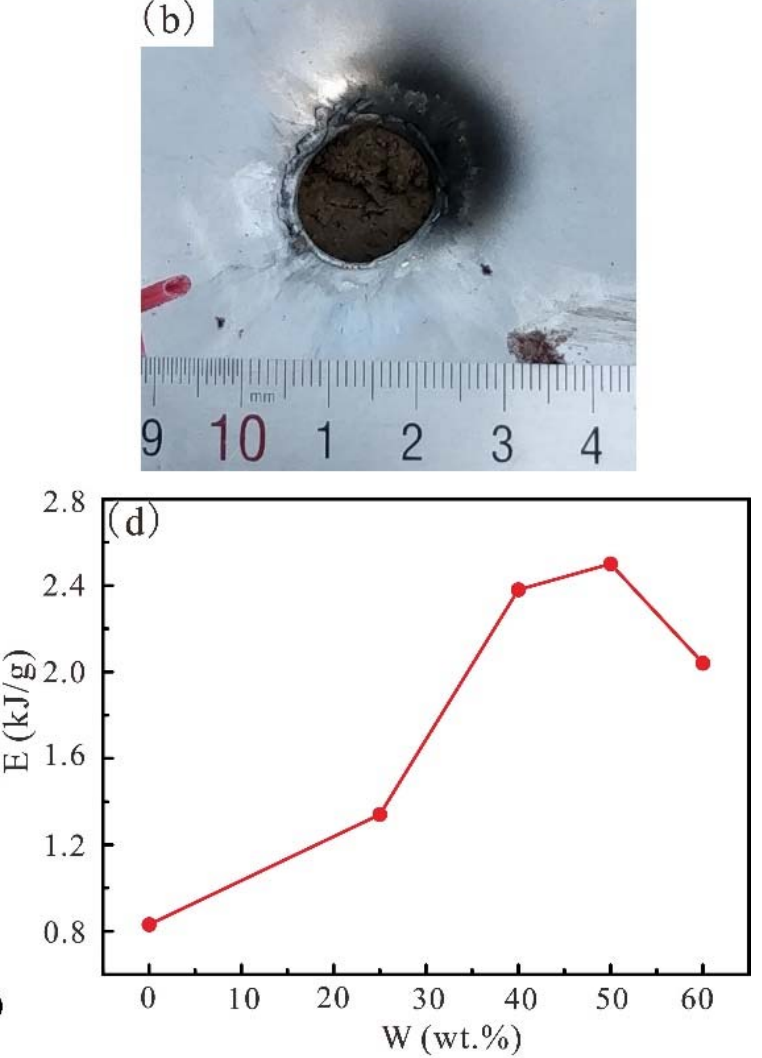

Figure 6. Energy release behaviors under high-speed impact loading. (a) The flame captured by a high-speed camera; (b) bullet hole; (c) quasi-static pressure inside test chamber; (d) relationship between released energy and the W content.

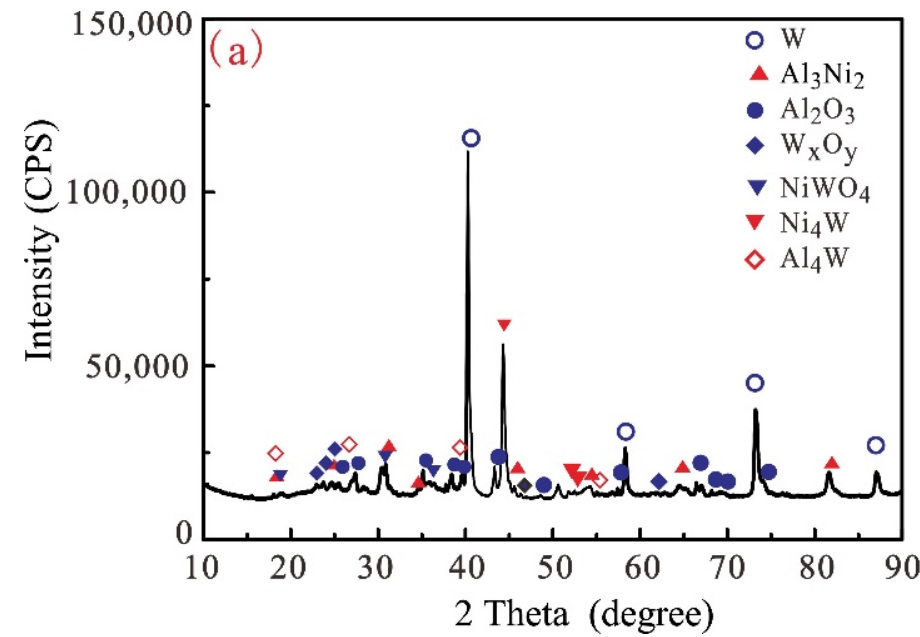

Figure 7. XRD patterns and SEM images of recovered (48Al-52Ni) ${ }_{100-x} \mathrm{~W}_{x}$ fragments. (a) XRD patterns; (b) irregular fragments; (c) magnified image for (b); (d) spherical particle; (e) magnified image for (d).

Combined with the reaction products generated in Ar (Figure 5), it can be known that $\mathrm{Al}$ and $\mathrm{Ni}$ in $(48 \mathrm{Al}-52 \mathrm{Ni})_{100-x} \mathrm{~W}_{x}$ composites react completely during impact loading, including the intermetallic reactions and oxidation reaction. The energy released by the reaction of $\mathrm{Al}$ and $\mathrm{Ni}$ makes some $\mathrm{W}$ participate in an intermetallic reaction. Compared with $\mathrm{Al}$ and $\mathrm{Ni}, \mathrm{W}$ has higher latent heat but lower activity. Thus, the reaction of $\mathrm{W}$ exactly enhances the released energy of the Al-Ni composites with W. 

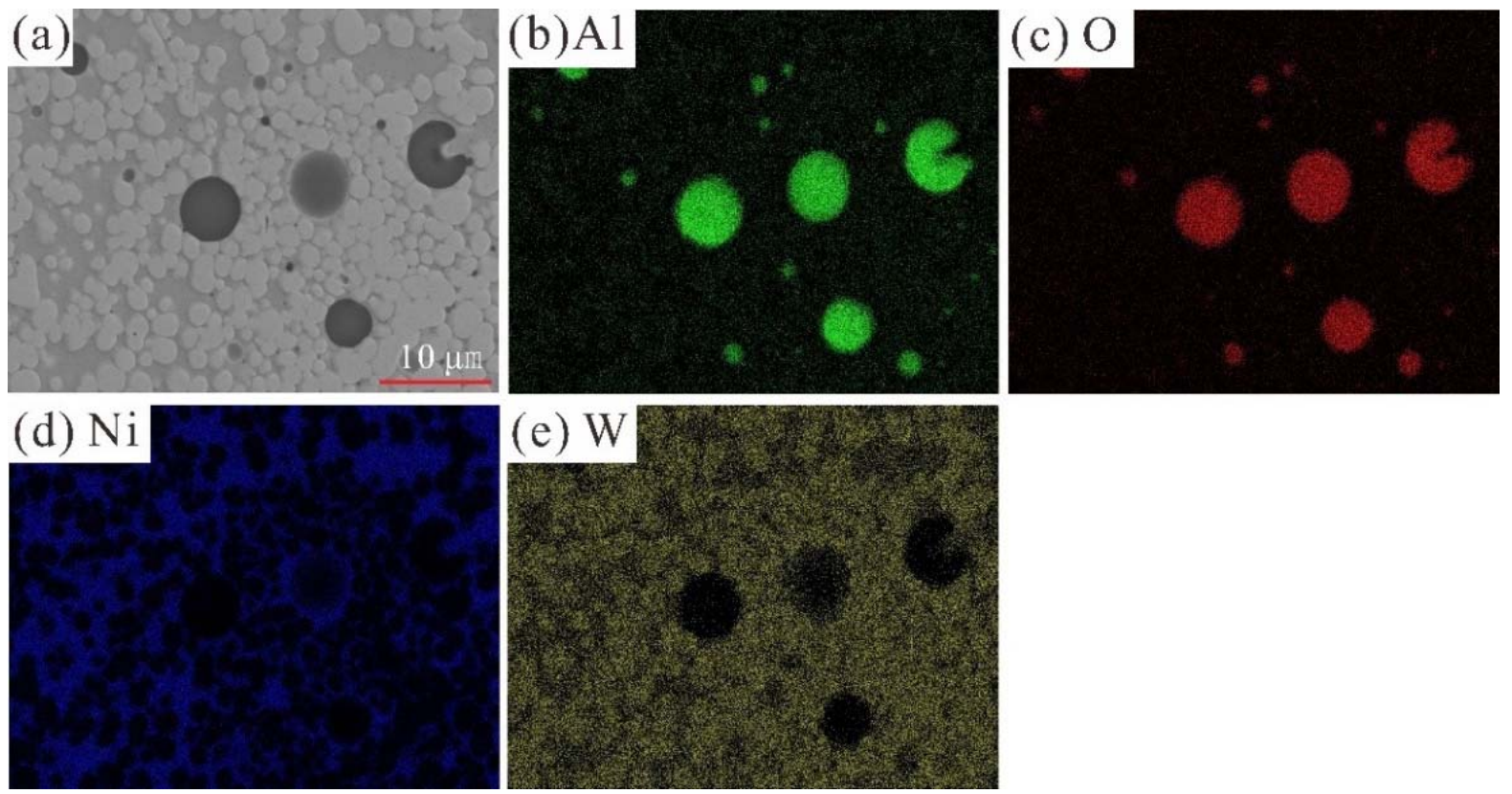

Figure 8. Elemental mapping of recovered (48Al-52Ni) $)_{100-x} \mathrm{~W}_{x}$ fragments.

On the other hand, the mechanical properties and fracture mechanism also have a significant influence on the released energy of composites. As shown in Figure 9, which shows the crack propagation for the compared Al-Ni composites with or without $\mathrm{W}$, the deformation in the 48Al-52Ni composites mainly occurs in the Al matrix. The mechanical properties of the composites are thus decided by those of the Al matrix. When $\mathrm{W}$ is introduced, the deformation and fracture in the $(48 \mathrm{Al}-52 \mathrm{Ni})_{100-x} \mathrm{~W}_{x}$ composites are concentrated at the interface between $\mathrm{Al}$ and $\mathrm{W}$. The mechanical properties of the (48Al$52 \mathrm{Ni})_{100-x} \mathrm{~W}_{x}$ composites are thus decided by the binding between $\mathrm{Al}$ and $\mathrm{W}$. As shown in Figures 1 and 2, the binding between $\mathrm{Al}$ and $\mathrm{W}$ in the $(48 \mathrm{Al}-52 \mathrm{Ni})_{100-x} \mathrm{~W}_{x}$ composites is a weak molecular binding without the formation of ionic bond or covalent bond. Therefore, the mechanical properties, especially the fracture strain, are clearly reduced in the composite with $\mathrm{W}$, as shown in Table 2. The brittle fracture means more fresh surface for the oxidation of constituent metals and a higher amount of energy released by the oxidation reaction. Therefore, the intermetallic reaction of $\mathrm{W}$ and the higher oxidation reaction of $\mathrm{Al}$ co-contribute to the higher amount of released energy of the composites with $\mathrm{W}$, as shown in Figure 6d.
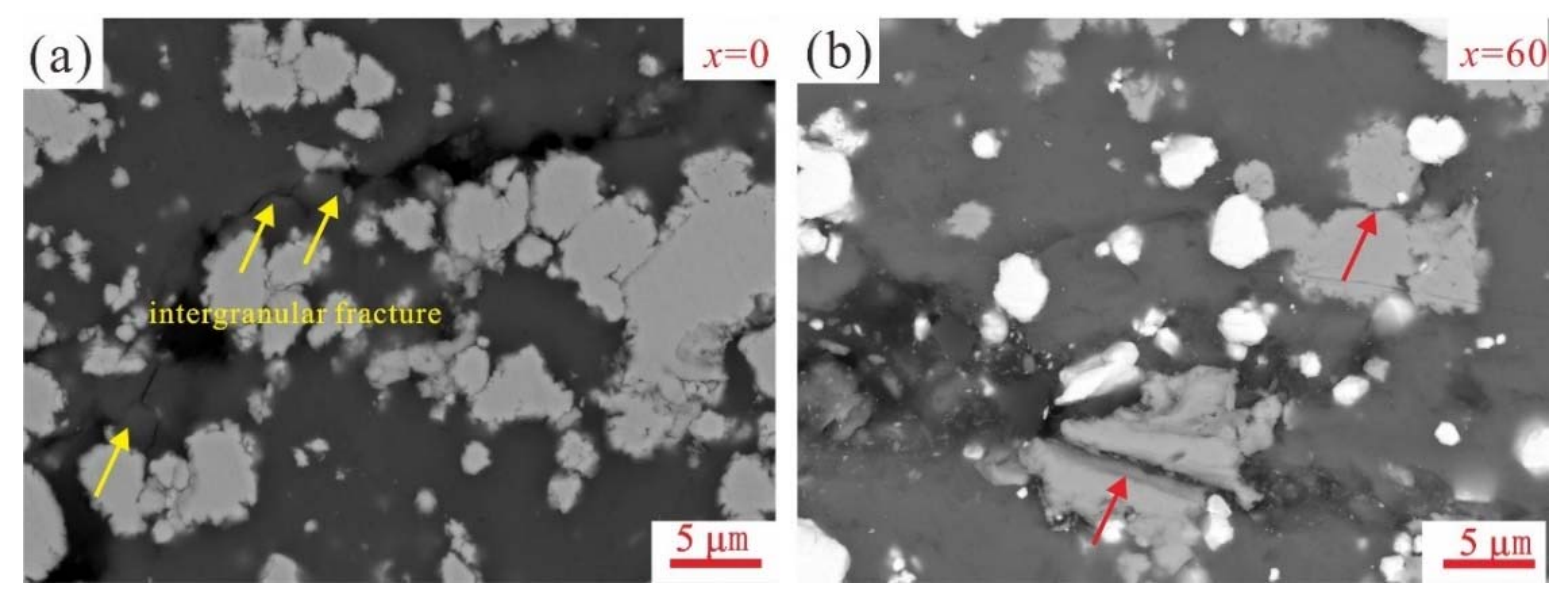

Figure 9. Crack propagation for $(48 \mathrm{Al}-52 \mathrm{Ni})_{100-x} \mathrm{~W}_{x}$ composites during compression. (a) $x=0$; (b) $x=60$. 
Table 2. Mechanical properties of $(48 \mathrm{Al}-52 \mathrm{Ni})_{100-x} \mathrm{~W}_{x}$ composites.

\begin{tabular}{cccccc}
\hline $\boldsymbol{x}$ & $\boldsymbol{\rho} / \mathbf{g} \cdot \mathbf{c m}^{-\mathbf{3}}$ & $\mathbf{T M D} / \%$ & $\sigma_{\mathbf{c}} / \mathbf{M P a}$ & $\boldsymbol{\sigma}_{\mathbf{c f}} / \mathbf{M P a}$ & $\varepsilon_{\mathbf{c f}} / \%$ \\
\hline 0 & 4.18 & 98.8 & $289 \pm 16$ & $480 \pm 31$ & 3.8 \\
25 & 4.13 & 98.20 & $296 \pm 18$ & $391 \pm 14$ & 1.8 \\
40 & 5.90 & 96.58 & $297 \pm 10$ & $381 \pm 8$ & 1.7 \\
50 & 6.66 & 96.50 & $323 \pm 6$ & $396 \pm 6$ & 1.7 \\
60 & 7.44 & 94.89 & $318 \pm 5$ & $400 \pm 2$ & 1.7 \\
\hline
\end{tabular}

$\sigma_{\mathrm{c}}$ is compressive yield strength; $\sigma_{\mathrm{cf}}$ is compressive fracture strength; $\varepsilon_{\mathrm{cf}}$ is compressive fracture strain.

\section{Conclusions}

In this work, $(48 \mathrm{Al}-52 \mathrm{Ni})_{100-x} \mathrm{~W}_{x}$ composites without intermetallics were prepared successfully by ball-milling and hot-pressing. The effects of $\mathrm{W}$ on the microstructure, thermal reaction behaviors, and impact-induced energy release behaviors of Al-Ni ESMs were systematically investigated. The following conclusions were obtained:

- $\quad$ The introduced spherical-like $\mathrm{W}$ particles were randomly distributed in the continuous $\mathrm{Al}$ matrix. The interfaces between $\mathrm{Al}$ and $\mathrm{Ni}$ decreased, while those between $\mathrm{Al}$ and $\mathrm{W}$ increased as $\mathrm{W}$ content in the composites increased. The surface state of $\mathrm{Al}$ and $\mathrm{Ni}$ were independent of the addition of $\mathrm{W}$.

- The stable surface state of $\mathrm{Al}$ and $\mathrm{Ni}$ led to similar onset temperatures of the $\mathrm{Al}-\mathrm{Ni}$ intermetallic reaction in $(48 \mathrm{Al}-52 \mathrm{Ni})_{100-x} \mathrm{~W}_{x}$ composites. The decrease in contact area between $\mathrm{Al}$ and $\mathrm{Ni}$ resulted in the decrease in reaction heat.

- It was shown that the energy released by the $\mathrm{Al}-\mathrm{Ni}$ intermetallic reaction could lead to the $\mathrm{W}-\mathrm{Al}$ intermetallic reaction and result in the absence of $\mathrm{Ni}_{3} \mathrm{Al}$ during the annealing at Ar atmosphere.

- During the impact process, $\mathrm{W}-\mathrm{Al}$ and $\mathrm{W}-\mathrm{Ni}$ intermetallic reactions could be caused by $\mathrm{Al}-\mathrm{Ni}$ intermetallic reactions as well as the oxidation reaction of $\mathrm{Al}$ and Ni. Meanwhile, more $\mathrm{Al}$ and $\mathrm{Ni}$ were oxidized due to more fresh metal surface related to the brittle fracture along the weak interface between $\mathrm{Al}$ and $\mathrm{W}$ particles. The participation of $\mathrm{W}-$ $\mathrm{Al}$ and $\mathrm{W}-\mathrm{Ni}$ in the intermetallic reaction, as well as the higher oxidation reaction of $\mathrm{Al}$ and $\mathrm{Ni}$, co-contributed to the greater amount of released energy of $(48 \mathrm{Al}-52 \mathrm{Ni})_{40} \mathrm{~W}_{60}$.

Author Contributions: Conceptualization, S.L., C.H. and Y.T.; methodology, J.C. and S.B.; formal analysis, C.H., Y.T. and S.B.; investigation, S.L. and C.H.; resources, S.L., Y.T. and S.B.; data curation, C.H. and J.C.; writing-original draft preparation, C.H. and Y.T.; writing-review and editing, S.L., C.H. and Y.T.; visualization, J.C. and S.B.; supervision, Y.T. and S.B.; project administration, Y.T. and S.B.; funding acquisition, S.L., Y.T. and S.B. All authors have read and agreed to the published version of the manuscript.

Funding: This research was funded by the National Natural Science Foundation of China, grant number 11972372.

Institutional Review Board Statement: Not applicable.

Informed Consent Statement: Not applicable.

Data Availability Statement: The raw/processed data that support the findings of this study are available from the corresponding author, Y.T., upon request.

Conflicts of Interest: The authors declare no conflict of interest.

\section{References}

1. Qiao, L.; Zhang, X.F.; He, Y.; Zhao, X.Y.; Guan, Z.W. Multiscale modelling on the shock-induced chemical reactions of multifunctional energetic structural materials. J. Appl. Phys. 2013, 113, 2129-2199. [CrossRef]

2. Zhou, J.; He, Y.; He, Y.; Wang, C.T. Investigation on impact initiation characteristics of fluoropolymer-matrix reactive materials. Propellants Explos. Pyrotech. 2017, 42, 603-615. [CrossRef]

3. Wang, Y.; Jiang, W.; Zhang, X.F.; Liu, H.Y.; Liu, Y.Q.; Li, F.S. Energy release characteristics of impact-initiated energetic aluminummagnesium mechanical alloy particles with nanometer-scale structure. Thermochim. Acta 2011, 512, 233-239. [CrossRef] 
4. Luo, P.G.; Wang, Z.C.; Jiang, C.L.; Mao, L.; Li, Q. Experimental study on impact-initiated characters of W/Zr energetic fragments. Mater. Des. 2015, 84, 72-78. [CrossRef]

5. Li, Y.; Wang, Z.C.; Jiang, C.L.; Niu, H.H. Experimental study on impact-induced reaction characteristics of PTFE/Ti composites enhanced by W particles. Materials 2017, 10, 175. [CrossRef] [PubMed]

6. Zhang, S.; Liu, J.X.; Yang, M.; Wang, L.; Lan, J.; Li, S.K.; He, C.; Xue, X.Y. Effects of multi-component co-addition on reaction characteristics and impact damage properties of reactive material. Mater. Des. 2018, 153, 1-8. [CrossRef]

7. Feng, B.; Fang, X.; Li, Y.C.; Wu, S.Z.; Mao, Y.M.; Wang, H.X. Reactions of Al-PTFE under impact and quasi-static compression. Adv. Mater. Sci. Eng. 2015, 2015, 582320. [CrossRef]

8. Sanders, V.E.; Asay, B.W.; Foley, T.J.; Tappan, B.C.; Pacheco, A.N.; Son, S.F. Reaction propagation of four nanoscale energetic composites $\left(\mathrm{Al} / \mathrm{MoO}_{3}, \mathrm{Al} / \mathrm{WO}_{3}, \mathrm{Al} / \mathrm{CuO}\right.$, and $\left.\mathrm{Bi}_{2} \mathrm{O}_{3}\right)$. J. Propuls. Power 2007, 23, 707-714. [CrossRef]

9. Aydelotte, B.B.; Thadhani, N.N. Mechanistic aspects of impact initiated reactions in explosively consolidated metal+aluminum powder mixtures. Mater. Sci. Eng. A 2013, 570, 164-171. [CrossRef]

10. Ren, H.L.; Liu, X.J.; Ning, J.G. Microstructure and mechanical properties of W-Zr reactive materials. Mater. Sci. Eng. A 2016, 660, 205-212. [CrossRef]

11. Kappagantula, K.S.; Farley, C.; Pantoya, M.L.; Horn, J. Tuning energetic material reactivity using surface functionalization of aluminum fuels. J. Phys. Chem. C 2012, 116, 24469. [CrossRef]

12. Xiong, W.; Zhang, X.F.; Wu, Y.; He, Y.; Wang, C.T.; Guo, L. Influence of additives on microstructures, mechanical properties and shock-induced reaction characteristics of Al/Ni composites. J. Alloys Compd. 2015, 648, 540-549. [CrossRef]

13. Dean, S.W.; Potter, J.K.; Yetter, R.A.; Eden, T.J.; Champagne, V.; Trexler, M. Energetic intermetallic materials formed by cold spray. Intermetallics 2013, 43, 121-130. [CrossRef]

14. Fischer, S.H.; Grubelich, M.C. A Survey of Combustible Metals, Thermites, and Intermetallics for Pyrotechnic Applications; AIAA Meeting Papers on Disc; American Institute of Aeronautics and Astronautics: Reston, VA, USA, 1996; Volume 96. [CrossRef]

15. Chen, Y.J.; Chen, J.; Wang, J. Dynamic mechanical behavior and energy release characteristics of Al-Ni-W reactive material. Ordance Mater. Sci. Eng. 2018, 4, 71-75. (In Chinese)

16. Rogachev, A.S.; Tolochko, B.P.; Lyakhov, N.Z.; Sharafutdinov, M.P.; Popkov, N.A.; Pirogov, B.Y.; Pis'menskaya, E.B. Characteristic features of structure formation of nickel monoaluminide formed in a gasless combustion wave. Crystallogr. Rep. 2003, 48, 466-468. [CrossRef]

17. Shchukin, A.S.; Sytschev, A.E. Effect of a NiO Additive on Interaction in a Ni-Al-W System in Self-Propagating High-Temperature Synthesis. Combust. Explos. Shock Waves 2018, 54, 433-441. [CrossRef]

18. Huang, C.M.; Chen, J.; Bai, S.X.; Li, S.; Tang, Y.; Liu, X.Y.; Ye, Y.C.; Zhu, L.A. Enhancement of energy release performance of Al-Ni composites by adding CuO. J. Alloys Compd. 2020, 835, 155271. [CrossRef]

19. Ames, R. Vented chamber calorimetry for impact-initiated energetic materials. In Proceedings of the 43rd AIAA Aerospace Sciences Meeting and Exhibit, Reno, Nevada, 10-13 January 2005; Volume 279.

20. White, J.D.; Reeves, R.V.; Son, S.F.; Mukasyan, A.S. Thermal explosion in Al-Ni system: Influence of mechanical activation. J. Phys. Chem. A 2009, 113, 13541-13547. [CrossRef]

21. Gasparyan, A.; Shteinberg, A. Macrokinetics of reaction and thermal explosion in $\mathrm{Ni}$ and $\mathrm{Al}$ powder mixtures. Combust. Explos. Shock Waves 1988, 24, 324-330. [CrossRef]

22. $\mathrm{Hu}, \mathrm{A} . ;$ Cai, S. Research on the novel Al-W alloy powder with high volumetric combustion enthalpy. J. Mater. Res. Technol. 2021, 13, 311-320. [CrossRef]

23. Biswas, A.; Roy, K.S. Comparison between the microstructural evolutions of two modes of SHS of NiAl: Key to a common reaction mechanism. Acta Mater. 2004, 52, 257-270. [CrossRef]

24. Murray, J.L. ASM handbook: Alloy phase diagrams. Mater. Park 1992, 3, 20.

25. Shchukin, A.S.; Sytschev, A. Fine structure of transition layer formed between NiAl melt and W substrate during self-propagating high-temperature synthesis. Lett. Mater. 2017, 7, 244-248. [CrossRef]

26. Sytschev, A.E. Synthesis of composite based on $\mathrm{W}-\mathrm{Ni}-\mathrm{Al}$ system by the electro-thermal explosion under pressure. Lett. Mater. 2018, 8, 274-277. [CrossRef] 